\title{
Determinants of Allocative, Cost and Scope Efficiencies: A Comparative Analysis of Banks and Insurance Companies in Pakistan
}

\author{
Maha Haroon (Corresponding author) \\ Karachi University Business School, University of Karachi \\ 75270, Sindh, Pakistan \\ Tel: 923-452-224-503Ｅ-mail: mahaharoon34@gmail.com \\ Dr. Danish Ahmed Siddiqui \\ Karachi University Business School, University of Karachi \\ 75270, Sindh, Pakistan. \\ Tel: 923-333-485-884Ｅ-mail: daanish79@ hotmail.com
}

Received: November 1, 2019 Accepted: November 18, 2019 Published: November 25, 2019

doi:10.5296/bms.v10i2.15903ＵRL: https://doi.org/10.5296/bms.v10i2.15903

\begin{abstract}
The purpose of this research paper is to empirically investigates determinants of allocative, cost and scope efficiencies as well as impact of financial crisis and stock market performance on efficiencies. Pakistan's banks and insurance companies' sector were taken for the purpose of comparative analysis. For this objective both Islamic/takaful and conventional sectors were occupied. Twelve years data (2007-2018) of PSX's banking and insurance sector was taken. Two stage non-parametric efficiency analysis was done, in the first stage, estimation for efficiency scores we used DEA for both sectors. In second phase, efficiency scores are regressed on the selected determinants by Tobit Regression. For measuring stock market performance CASR is calculated. Inadequate efficiency in insurance sector is evidenced against banking sector. Efficiency of takaful firms as new entrants of the market was not good comparatively to conventional insurance firms. Islamic and conventional banks are operated at almost same efficiency level. Performance of stock market has inverse and both (significant and insignificant) relationship with efficiency, means different events and


fundamentals don't affect the performance of sectors that is why efficiencies are not hit by this way. As well as determinants have different relationship with allocative, cost and scope efficiencies scores.

Keywords: DEA; Cost, Allocative and Scale efficiencies; Variable return to scale; 2 stage non-parametric; Banks and Insurance.

\section{Introduction}

\subsection{Background of the Study}

For the development and progress of country's economy, the financial sector plays a crucial role. In this regard, Pakistan seems to have shown bad luck. At the time of independence, Pakistan didn't inherit a stable financial sector. But after that, this sector started emerging and observed slow growth. Now, a well-developed integration of institutions is observable in financial sector of Pakistan comprising Commercial Banks, Microfinance Banks, Leasing Companies, DFIs, Investment Banks, Housing Finance, Venture Capital, Modaraba Companies, Insurance Companies, Exchange Companies and Mutual Funds. The financial sector is regulated and supervised by Securities and Exchange Commission, State Bank of Pakistan and Controller of Insurance (SBP).

In developed and emerging markets of the world, many studies have been analyzed about the efficiency of financial sector. Mainly insurance companies and banks are financial institutions that are an important part of any country's financial system.

Two financial sectors are focused in this study, Banks (conventional and Islamic) and Insurance Companies (conventional and takaful). Islamic banking being a vital component of Ethical Banking System its procedures are built on Islamic (Shariah) laws. Islamic banking wholly prohibits interest and generally known as asset-based financing. Contrary, an unethical banking system is known as conventional banking and leads by Man-Made Laws. It focuses on financial gains (profit-oriented) and makes money by way of interest Brown, (2019). Takaful (also known as Islamic insurance) is different from conventional insurance because it didn't contain forbidden unendurable elements like gharar (ambiguity), riba (usury) and maysir (gambling). Distinct to conventional insurance, takaful stands on the pillars like mutual protection and assurance, shared assistance, concept of tabarru' (donation) and mutual security and responsibility Antonio et al., (2013).

For the economic development of any country, an advanced and well-functioning banking sector is obligatory. Sufian et al., (2016) Banking sector provides important financial intermediation function for transforming deposits into fruitful investments. As an alternative to conventional banking, Islamic banking has been introduced in various countries recently, yet its growth is speedy Sardar et al., (2011). Through equity participation, Islamic banks make profit which requires a borrower to give a share in their profits to the bank rather than paying interest. 
Generally, risk transfer mechanism is known as the primary function of insurance because it gives peace of mind and assist to hedge future losses. In addition, the Non-Bank Financial Institution has become an alternate source of funding than Banking and protecting against business risks or anything related to the economy Rusydiana \& Nugroho, (2017). Most of the population comprises of Muslim and Islamic finance has evolved as most flourishing sector of the international financial system. According to many reports, the introduction of an Islamic model of insurance has encouraged the Islamic world economy. Insurance has become the biggest industry in economy of Saudi Arabia and has overtaken the banking, real estate and manufacturing sectors Rahman, (2013). A remarkable expansion has been evidenced in insurance sector due to the opening of Takaful firms in current years Abbas et al., (2018). Grmanová \& Strunz, (2017) for the achievement of goals, relationship between efficiency and profitability are important in insurance companies. There are two major sources of revenue which are premium and investment income of insurance companies in Pakistan Hussain, (2015).

After the Great Depression of 1930, the International Financial Crisis of 2008 has had the most horrible and dangerous influence on the world economies. The crisis also badly affected Pakistan's economy which faced extraordinary macroeconomic discrepancies and inequalities. Mughal, (2015). Khawaja et al., (2007) debated that existed economic fundamentals didn't allow an activist fiscal policy to cope with the crisis. Modest income countries such as Pakistan has directly affected by international crisis because domestic financial sector is segregated with the international financial sector (IMF, 2009).

\subsection{Efficiency Concepts}

The microeconomic concepts, viz. consumer theory and producer theory are reflected in the concept of efficiency. Former concept states about the utility maximization, whereas the later attempts to profit maximization Antonio et al., (2013). According to Worthington \& Hurley, (2000) and Ali et al., (2010) efficiency is categorized as operational, allocative and scope efficiencies. It is said that when a bank/firm is functionally efficient, it produces additional output units for a certain input level (also known as technical efficiency). Usage of technology can make it possible to achieve this target (pure technical efficiency) or large-scale production (scale efficiency). Another way to achieve efficiency is to allocate resources in such a way that will decline the effective cost of production (allocative efficiency). Cost Efficiency is an aggregate measure of allocative and technical efficiency hence expansions in both efficiencies are replicated in cost. Only a bank/firm can become cost efficient that is technically and allocatively efficient.

These stated equations sum up the inter-relationships between technical, allocative and scope efficiencies.

Technical efficiency $($ TE $)=$ PTE $*$ SE.... (i)

Allocative efficiency $(\mathrm{AE})=\mathrm{CE} / \mathrm{TE}$.... (ii) 


\section{Scope efficiency $(\mathrm{SCE})=\mathrm{CE} / \mathrm{SE} . .$. (iii)}

\begin{tabular}{|l|l|}
\hline Description & Symbols \\
\hline Pure technical efficiency & PTE \\
\hline Scale efficiency & SE \\
\hline Technical efficiency & TE \\
\hline Cost efficiency & CE \\
\hline
\end{tabular}

Briefly, it has been seen that those firms are able to allocate their resources in the most effective way that are technically efficient with powerful information symmetry, which in return higher levels of cost efficiency is achieved.

\subsection{Problem Statement}

Pakistan as an evolving economy combat many fundamental risk factors i.e. (political instability, financial crisis, volatility in stock returns and efficiency problems) in recent years. Pakistan's major insurance companies which have a global presence confronted acute financial adversities in the financial crises of 2007-2010 (SBP). According to Mughal et al., (2015) the economy of Pakistan that was already facing great macroeconomic discrepancies and instabilities was also badly affected by global financial crisis of 2008. Pakistan economy was pushed further into financial crisis by the world crisis.

Performance analysis estimates how well a corporation can utilize its resources to generate revenue such as ROI, ROA, Value added and so on while efficiency analysis measures the output generated from the given level of input. Kader et al., (2010) although most of the Takaful insurers aren't publicly listed, economic performance's direct market measures (i.e. alpha or the market-to-book ratio) are usually not really helpful. Also inspects the association between efficiency of bank and performance of share. Efficiency analysis is more useful because it indicates the level of wastage associated in achieving a particular result and is highlighted where improvements are most needed.

Maqbool et al., (2018) Political instability and international events are one of the most essential factors that have an impact on stock market returns of the stock exchange's sector furthermore this condition exploits the efficiency of stock market sectors.

New-fangled standards in financial risk management and operational efficiencies and advancements in overall administrative practices are necessary to raise performance of banks and insurance companies. The Pakistan's insurance sector has undoubtedly a massive potential which has not been realized as yet (SBP). Khan et al., (2018) government banks are less technically efficient than private banks; small and medium-size banks are less technically efficient than large banks and in efficiency Islamic commercial banks follow conventional commercial banks. Qureshi \& Shaikh, (2012) Islamic bank is less revenue efficient and more cost efficient. Noreen \& Ahmad, (2016) It is concluded that insurance sector of Pakistan is $58 \%$ cost efficient. 
For the betterment of previous literature this research plays a pivotal role. Most of the researches addresses single efficiency's type and based on productivity and profitability measures. This research investigates three types of interrelated efficiencies, such as, allocative, cost, and scope efficiency as well as stock market fluctuations and financial crisis impact on efficiencies.

\subsection{Gap Analysis}

This is the first research which makes comparison between two renowned financial sectors in Pakistan. One of which is developed which kept the history before independence (Banks) and the other is developing sector which have a great potential (Insurance Companies) and analyses both branches (Islamic/takaful and conventional) of both sectors; conventional banks to conventional insurance and Islamic banks to Islamic Insurance. Pakistan's Stock Market Sectors are taken for this purpose. In finest of our knowledge, this investigation is one of the few among researches that addresses the combination of allocative, cost and scope efficiency. Abbas et al., (2018) studies the performance of Allocative, Cost and Technical efficiencies of Pakistan's Conventional and Takaful Insurance Firm. Almost same efficiency level is found both in Takaful and insurance firms. According to Hamid \& Khurram, (2017) Islamic banks are less technically efficient than conventional banks.

Furthermore, it uses firm specific variables for determinants of efficiencies so that a clear picture of firm internal operations can be analyzed. S. Nair \& Vinod, (2018) examine the determinants of allocative, scope and cost efficiencies of Indian Scheduled Commercial Banks. Size does matter among factors that can have an impact on efficiency. They also concluded that overall efficiency is improved by efficiency of Larger and Foreign SCBs.

No insight has been given in previous researches about impression of International Financial Crisis and volatility of Stock Market Returns on firm's efficiency in context of Pakistan. Hadad et al., (2019) discovered that the bank efficiency is positively linked to JCI index of the Indonesian Stock Exchange. According to Yakubu \& Akerele, (2012) Nigerian stock exchange doesn't have noteworthy impact on the 2008 global financial crisis. Eltivia et al., (2014) examine the Indonesia's listed banks' impact of cost efficiency on stock performance. Conclusion evidences that stock performance is not affected by cost efficiency because Shareholders ignore the cost of the company in front of the company's profits.

Various researches address either efficiencies of banking sector or insurance sector in Pakistan. So, it is an attempt that will add special essence in the field of research by comparing efficiencies of these two sectors along with impact of stock market performance and financial crisis on efficiencies.

\subsection{Research Objectives}

The main purpose is to analyze the determinants of efficiencies of Pakistan's two financial sector (insurance companies and banks). Allocative Efficiency, Cost Efficiency and Scope Efficiency of Conventional and Islamic/takaful banks and insurance companies of Pakistan 
are measured for the period of 2007-2018. For the reason, the study analyzes the stock market sector of Pakistan as a sample. This research paper uses firm level data of 20 banks and 30 companies of insurance industry of Pakistan. Initially, for the estimation of efficiency of Pakistan's banks and insurance companies we used the Data Envelopment Analysis (DEA) (which is the non-parametric approach) on the data set of companies. Secondly, to find the regression results, findings of efficiencies are used as dependent variable. The collection of this study suggests that significance and signs of the coefficients of firm-specific variables deviate across sample period.

The primary objectives of this study that will be analyzed are:

1. To determine the sector specific variables relating to allocative, cost and scope efficiencies.

2. To analyze impact of stock market performance and financial crisis on efficiencies.

\subsection{Significance}

Efficiency analysis is significant to identify and control:

1. The inefficient use of resources and wastage of resources.

2. Cost effectiveness of the sector(s).

3. Events that limit the efficiency.

It enhances attractiveness the sector:

1. For customers

2. For investors

3. Progressive for provision more service products.

\subsection{Limitations}

4. Variables like indicators of the quality service offered, taxation and regulation as well as exchange rate could be included in the future research.

5. Non-parametric Malmquist Productivity Index (MPI) is a useful method that could be exercised for inspecting productivity changes because technologies are changing as time passes or technical changes or inclusion of different regressor than present.

Organization of the study:

The structure of the study encompasses of five section. First section covers background of study and efficiency concept. Second section cover the literature review. Third section describes methodology (DEA approach and Tobit regression), and data and variables used in the study. Fourth section states experimental analysis and results, and Last section entitled as conclusion. 
Subsequently empirical literature. Next chapter defines methodology (DEA approach and Tobit regression) and data and selection of variables and fourth unit states experimental analysis and results and Last chapter has a conclusion of this paper.

\section{Literature Review}

For a long time, efficiency of financial system has been subject of interest for decision makers. However, the interest on the issue has intensified considerably in the recent times especially after the global financial meltdown which has triggered many financial institutions towards the verge of insolvency. Therefore, it's been a stringent debate between academia about relationship of efficiency of financial system with stability and risk aversion. Various methods have been used to estimate efficiency along with contrasting econometric approaches are used to find which factors affect efficiency of bank and insurance. Many national and international (developed and emerging economies) studies on the efficiency of bank and insurance company have been conducted. Some literature has been presented here that best bolster our research.

Aygören et al., (2015) concentration and capital adequacy ratios positively impact stock's efficiency, whereas the number of employees per unit of branches and age affects stocks negatively. The results also display that investors realize efficiency to be an important factor in regard of stock performance. Aftab et al., (2011) suggested, change in annual bank efficiency and share performance have a positive and significant association. Jurčevic \& Žaja, (2013) In Republic of Croatia, lowest efficiency scores had been observed in 2007 for banks and insurance industry but 2008 is also worth seeing for banks. Xianga et al., (2011) conducts a relative study on Canadian, UK and Australian banks. Evidences of recent global financial crisis direct that Canadian and UK banks show inferior efficiency in contrast to their Australian analogues.

Furthermore, it uses firm specific variables for determinants of efficiencies so that a clear picture of firm internal operations can be analyzed. Aziz et al., (2016) as compare to conventional banks, Islamic banks demonstrate good performance regarding asset quality, efficiency and return, although, Islamic banks are struggling concerning investment, deposits, advances, capital and liquidity in Pakistan. Islamic banks charge with depositors higher spread and share of distributable income over conventional banks. S. Nair \& Vinod, (2018) size does matter among factors that can have an impact on efficiency of Indian Scheduled Commercial Banks. They also concluded that overall efficiency is improved by efficiency of Larger and Foreign SCBs. Nourani et al., (2018) estimates technical efficiency of insurance companies in Malaysian. They divided insurance companies into premium accumulation and investment capability. The conclusions disclose inefficiency in the investment capability of local insurer. Superior efficiency in the premium accumulation has been attained in the general segment. Miah \& Uddin (2017) analyzed the stability, efficiency and business orientation between conventional and Islamic banks. Islamic banks are less cost-efficient and more concrete in case of short-term stability as compared to conventional counterparts. 
Furthermore, larger banks show dis-economies of scale due to less intermediation ratio. Well capitalized banks are unable to exploit from leverage because of cost-inefficiency.

Janjua \& Akmal, (2015) investigated the Islamic and conventional insurance sector's economic efficiency in Pakistan. Outcomes of DEA show worse economic efficiency of conventional insurance over Islamic insurance. While ratio analysis demonstrates better efficiency of conventional counterparts against Takaful. Over the period, the profitability of Takaful companies was not very satisfactory because of market's new entrants, so improved economic efficiency has been observed in conventional insurance. Taib et al., (2018) also computed the Efficiencies (Technical, Pure Technical and Scale efficiencies) in Pakistan. Primarily, scale inefficiency was detected, instead of technical and pure technical inefficiency. Most of the firms are performing with the increment of return to scale which indicates that their efficiency and scope to attain the optimal level of output can be increased.

Nazir et al., (2012) financial performance has been checked due to global financial crisis of Pakistan's Banks. Asset quality was found as important determinant of asset return subsequently bank size and solvency. They demonstrated that financial performance is adversely affected by asset quality and deposit. Contrary; advances, size, liquidity, investment and solvency have constructive impacts on the financial performance of the banks. According to Hamid \& Khurram, (2017) Islamic banks are less technically efficient than conventional banks.

No insight has been given in previous researches about impression of International Financial Crisis and volatility of Stock Market Returns on firm's efficiency in context of Pakistan. Hadad et al., (2019) discovered that the bank efficiency is positively linked to JCI index of the Indonesian Stock Exchange. According to Yakubu \& Akerele, (2012) Nigerian stock exchange doesn't have noteworthy impact on the 2008 global financial crisis. Eltivia et al., (2014) examine the Indonesia's listed banks' impact of cost efficiency on stock performance. Conclusion evidences that stock performance is not affected by cost efficiency because Shareholders ignore the cost of the company in front of the company's profits.

\section{Methodology}

This study has adopted two-stage approach as followed by S. Nair \& R, (2018); Biener et al., (2015). In first stage, the study will measure efficiencies through DEA approach; in the second stage, it will regress the estimated efficiency measures on the set of determinants.

Two different approaches i.e. parametric and non-parametric approaches are used to measure efficiency. Parametric approach is frequently used for statistically normal data, such as, Distribution Free Approach (DFA), Stochastic Frontier Approach (SFA) and Thick Frontier Approach (TFA); whereas non-parametric approach uses other sets of data, such as, Free Disposable Hull (FDH) and Data Envelopment Analysis (DEA). Intermediation approach is being used for the measurement of input-output variables. Data Envelopment Analysis (DEA) technique uses these variables for measuring efficiencies (Cost, Allocative, Scope) and then Tobit Regression Model is being used to further investigate the determinants of efficiency. 


\subsection{Data Envelop Analysis}

Charnes et al. (1978) introduced Data Envelopment Analysis (DEA) that works on the methodology of mathematical programming approach. This method has drawn from the idea of Farrell (1957) about the concept of efficiency. Charnes et al. (1978) states that efficiency is calculated by DEA through constant returns to scale, while Banker et al. (1984) suggested, under the supposition of variable returns to scale. For each DMU, the result will present in arrangement of scores. Representation of score are: ' 1 ' $=100 \%$ efficient whereas ' $>1$ ' $=>100 \%$. As well as inefficiency of DMUs are also denoted by these scores.

\subsection{Sample Selection}

It is an attempt to investigate the whole Insurance sector and Banking Sector of Pakistan Stock Exchange. A comparative study is conducted between banks (conventional and Islamic) and insurance companies (conventional and takaful). Sample is selected randomly hence; it can be stated that the sample size incorporated in this research paper is almost $100 \%$ representative of the market share of Pakistan's insurance sector as well as banking sector. The Data Sample consist of (15 conventional and 5 Islamic) banks and (25 conventional and 5 takaful) insurance companies working in the country. The 12 years annual panel data of Pakistani Islamic and conventional insurance companies and banks is gathered for the period of 2007 to 2018. Information of variables are obtained from the repository of IAP (Insurance Association of Pakistan), SBP, Pakistan economic survey as well as published annual reports of each individual bank and insurance company.

\subsection{Stage 1: Efficiencies Analysis}

\subsubsection{Variables' Description of DEA}

Input and Output variables need to be elucidated to conduct a DEA estimation. In order to define the behavior of input-output relationship in financial institution four main approaches (asset, intermediation, profit, and production approach) have been established. Rusydiana, (2017); Wise, (2018); Antonio et al., (2013); Abidin, (2011) suggested these input and output variables to measure cost, allocative and scope efficiency in Insurance Sector.

\begin{tabular}{|l|l|}
\hline Variables & Description \\
\hline Inputs & \\
\hline Commission Cost & Commission Cost \\
\hline Management Cost & Management Cost \\
\hline Outputs & \\
\hline Gross Premium & Gross Premium \\
\hline Investment Income & Investment Income \\
\hline Input Prices & \\
\hline Commission Cost & commission expense : total sales \\
\hline Management Cost & management expense : total fund assets \\
\hline
\end{tabular}


These variables are used to measure allocative, cost, and scope efficiency of Banks S. Nair \& Vinod (2018); Adjei-Frimpong et al., (2014); Effendi et al. (2013); Banna et al., (2017).

\begin{tabular}{|l|l|}
\hline Variables & Description \\
\hline Inputs & Interest Cost \\
\hline Interest Cost & $\begin{array}{l}\text { Personnel expenses of bank staff such as } \\
\text { salaries, wages and benefits }\end{array}$ \\
\hline Operating Cost & Non-interest expenses \\
\hline Provisions for loan losses & Provisions for loan losses \\
\hline Outputs & Total customers' loans \\
\hline Advances & $\begin{array}{l}\text { Banks' investments in different types of } \\
\text { securities (e.g. government securities, } \\
\text { bonds, Treasury bill and equity investment) }\end{array}$ \\
\hline Other earning assets & Interest expenses/total deposits \\
\hline Input Prices & employee expense/total assets \\
\hline Interest Cost & non-interest expense/fixed asset \\
\hline Employee Cost & provision for loan losses/total advances \\
\hline Operating Cost & \\
\hline Provisions for loan losses &
\end{tabular}

\subsubsection{Independent $t$ Test}

Independent $\mathrm{t}$ Test is used to analyze mean values of two independent samples (like conventional and Islamic). It constructs statistical evidence regarding sample means, even if significant or insignificant. When significant level of T-test's probabilities is greater than desired $\mathrm{p} \leq 0.05$, homogeneity of variance is considered, means assumption of equal variances are not violated and null hypothesis (Ho) will be accepted.

\subsection{Stage 2: Tobit Regression}

In 1958, James Tobin proposed the statistical model which is generally known as Tobit Regression Model. It is used to define the relationship between an independent and a non-negative dependent variable. latent variable beta straightly depends upon the independent variable that establishes the affiliation between the latent variable and independent variable. Tobit regression is generally used as the best suited model if the dependent variable has found these types of characteristics:
i) Binary
ii) Has a constrained range
iii) Continuous
iv) Has a positive value. 


\subsubsection{Variables' Descriptions of Tobit Regression:}

Tobit Regression is performed on set of determinants, as independent variables, that affect banking sector as well as insurance sector, and the estimated efficiency measures, as dependent variables. For identifying drivers of firm efficiency, we examine the influence of firm-specific determinants. In this regard, certain explanatory independent variables are used:

\begin{tabular}{|c|c|c|}
\hline Variables & Proxies & Symbols \\
\hline \multicolumn{3}{|l|}{ Independent Variables } \\
\hline Age & Number of years operation & A \\
\hline Size & Total Assets & $S$ \\
\hline Leverage & Total Debt/Total Assets & $\mathrm{L}$ \\
\hline Capital Adequacy Ratio & Equity/Total Assets & CAR \\
\hline Return on Asset & Net income/Total Assets & ROA \\
\hline \multicolumn{3}{|l|}{ Dependent Variables } \\
\hline Cost Efficiency & & $\mathrm{CE}$ \\
\hline Allocative Efficiency & & $\mathrm{AE}$ \\
\hline Scope Efficiency & & SE \\
\hline \multicolumn{3}{|l|}{ Dummy Variables } \\
\hline Global Financial Crisis & $\begin{array}{l}2007-2008 \text { considered crisis } \\
\text { period. GFC considered ' } 1 \text { ' } \\
\text { and Post GFC considered ' } 0 \text { '. }\end{array}$ & GFC \\
\hline Islamic Firms & $\begin{array}{l}\text { Takaful firms and Islamic } \\
\text { banks considered ' } 1 \text { ' while } \\
\text { conventional firms and banks } \\
\text { considered ' } 0 \text { '. }\end{array}$ & Isl \\
\hline \multicolumn{3}{|l|}{ Impact checking Variable } \\
\hline Stock Market Performance & $\begin{array}{l}\text { Cumulative Annual Stock } \\
\text { Returns }\end{array}$ & CASR \\
\hline
\end{tabular}

\subsubsection{Age}

This independent variable defines the years of operation of any company within Pakistan's banking and Insurance sector. 'Learning curve theory' phenomena is addressed by this proxy, in which a process is jointly repeated by individuals or organizations. Abbas et al. (2018); Biener et al., (2015).

\subsubsection{Size}

Total Sales or Total Assets of the company are used by this proxy. In this research, Company's Total Asset is used as proxy for firm size. Hardwick (1997) claimed that due to operational cost efficiency there should be a beneficial affiliation between the size and performance of the firm which helps to lift the output and cut off the cost of units. As larger the size of the company, the greater the customers effectively diverge their estimated risks 
and respond more hastily to modifications in market conditions. Abbas et al., (2018); Biener et al., (2015); Khan et al., (2015); Banna et al., (2017); Řepková, (2015).

\subsubsection{Leverage}

Leverage is the amount of debt that a firm uses to finance its assets. A firm is said to be highly leveraged when it adds more debt than equity to invest its assets. Leverage is of two types; financial leverage (Debt to Equity or Debt to Asset) and the other is operating leverage. Financial leverage is solely used in this study so Total Debt / Total Asset is selected as the proxy measure. Abbas et al., (2018); Biener et al., (2015); Khan et al., (2015).

\subsubsection{Capital Adequacy Ratio (CAR)}

Capital Adequacy Ratio found optimistic relationship between efficiency and Equity/Asset (EQA) which means higher is the equity to asset ratio (EQA), the lesser is the requirement for exterior capital and hence higher profitability. Abugamea, (2018); NDLOVU, (2015); Banna et al., (2017).

\subsubsection{Return on Asset (ROA)}

ROA is the ratio of the net income over total assets. It is usually used as profitability indicator and shows how well the firm's investment resources can be used to generate profits by the firm management. Efficient utilization and revenue generation proficiency can be determined from the assets of any enterprise. Yao et al., (2018); Abugamea, (2018).

\subsection{Regression Equation}

Three Dependent Variables (Allocative, Cost and Scope Efficiency scores) are used which have been calculated through Data Envelop Analysis. Moreover, determinants of efficiencies are independent variables that are used to evaluate the company's efficiency. Cumulative Annual Stock Returns (CASR) use to predict the performance of PSX. To observe future behavior, the 12 years past association with variables is studied. Dummy variables of the study are "Islamic Firms" and "Conventional Firms" and "Global Financial Crisis" and "Post Global Financial Crisis". Dummy Variable which is considered absent = "0", while Dummy Variable which is considered present $=" 1 "$ in this regression model.

These model equations are equally applicable to Banking and Insurance sector.

DEA Scores CE (it) $=\alpha+\beta_{1} \mathrm{~A}$ (it) $+\beta 2 \mathrm{~S}$ (it) $+\beta 3 \mathrm{~L}$ (it) $+\beta 4$ CAR (it) + 35 ROA (it) $+\beta 6$ CASR (it) $+\beta)$ GFC_d $+\beta)$ isl_d $+\varepsilon$ (it)

DEA Scores AE (it) $=\alpha+\beta 1$ A (it) $+\beta 2 \mathrm{~S}$ (it) $+\beta 3 \mathrm{~L}$ (it) $+\beta 4$ CAR (it) $+\beta 5$ ROA (it) $+\beta 6$ CASR (it) $+\beta)$ GFC_d $+\beta)$ isl_d $+\varepsilon$ (it)

DEA Scores SE (it) $=\alpha+\beta 1$ A (it) $+\beta 2$ S (it) $+\beta 3$ L (it) $+\beta 4$ CAR (it) $+\beta 5$ ROA (it) $+\beta 6$ CASR (it) $+\beta)$ GFC_d $+\beta)$ isl_d $+\varepsilon$ (it) 
Table 1. Descriptive statistics

Insurance Sector

\begin{tabular}{|l|l|l|l|l|l|l|}
\hline & Observation & Mean & Median & Maximum & Minimum & Std. Dev. \\
\hline CE & 360 & 0.471162 & 0.386265 & 1 & 0 & 0.320934 \\
AE & 360 & 0.610628 & 0.592597 & 3.63972 & 0 & 0.375541 \\
SE & 360 & 0.50779 & 0.395831 & 3.09338 & 0 & 0.410398 \\
Size & 360 & 8595.722 & 1662 & 139626 & 0 & 18234.65 \\
Leverage & 360 & 0.565944 & 0.560242 & 0.973203 & 0 & 0.227339 \\
ROA & 360 & 0.029281 & 0.0317 & 0.8548 & -0.9386 & 0.114542 \\
CAR & 360 & 0.398249 & 0.41305 & 0.9747 & -0.2238 & 0.216716 \\
Age & 360 & 42.36667 & 36.5 & 87 & 11 & 26.13931 \\
CASR & 360 & 24073.33 & 21083.24 & 47806.97 & 5865.01 & 724.3157 \\
\hline
\end{tabular}

Table 2. Descriptive statistics

\section{Banking Sector}

\begin{tabular}{|l|l|l|l|l|l|l|}
\hline & Observation & Mean & Median & Maximum & Minimum & Std. Dev. \\
\hline CE & 240 & 0.732475 & 0.79392 & 1 & 0 & 0.270906 \\
AE & 240 & 0.789998 & 0.868317 & 1.241673 & 0 & 0.271259 \\
SE & 240 & 0.774651 & 0.83774 & 1.241673 & 0 & 0.27078 \\
Size & 240 & 417338.4 & 255600 & 3025853 & 0 & 484197.7 \\
Leverage & 240 & 900.9092 & 0.920708 & 216005 & 0 & 13943.01 \\
ROA & 240 & 0.006073 & 0.00795 & 0.75 & -0.192 & 0.05555 \\
CAR & 240 & 0.166006 & 0.1384 & 0.5704 & 0 & 0.106876 \\
Age & 240 & 36.25 & 27 & 156 & 12 & 33.2399 \\
CASR & 240 & 24073.33 & 21083.24 & 47806.97 & 5865.01 & 887.7203 \\
\hline
\end{tabular}

These statistics deal with insurance and banking sectors. The mean value of total assets of Pakistan's insurance sector is Rs. 8595.722 million whereas, the banking sector has a mean value of Rs. 417338.4 million. The average efficiency scores (CE, AE, SE) of insurance companies are 0.471162, 0.610628, 0.50779 while, banks have 0.732475, 0.789998, 0.774651 respectively. Average ROA and CAR of insurance and banking sectors are (3\% and $40 \%)$ and (1\% and 17\%) separately. Assets of sectors are more volatile across Pakistan which means that there is a capacity of improvement in insurance and banking sectors. Leverage of insurance sector has average value of about 57\% and banking sector has 900.9092. Mean ages of Pakistan's insurance and banking sector are 42 and 36 years. An average of 24073.33 is showed by both sectors of stock market.

According to efficiency scores, Pakistan's banking sector is more operationally efficient than insurance sector, but insurance sector is more profitable because Return on Assets and Capital Adequacy Ratio is higher as compared to banks. 


\section{$\triangle$ Macrothink}

\section{Empirical Findings}

\subsection{Results of Stage 1}

\subsubsection{Efficiencies Analysis}

In stage one, Data Envelop Analysis is performed for the evaluation of efficiency scores. For this purpose, variable returns, input-oriented approach of DEA is used for BCC-I and COST-C models. Results show that efficiency scores of conventional (banks and firms) and Islamic (banks and firms) are ranked according to their respective scores i.e. top ranked firms as $100 \%$ efficient and the rest are ranked accordingly.

Table 3. year-wise mean efficiency scores

\begin{tabular}{|c|c|c|c|c|c|}
\hline & \multicolumn{4}{|c|}{ INSURANCE COMPANIES } \\
\hline & & $\mathbf{C E}$ & $\mathbf{A E}$ & SE & VRS \\
\hline \multirow[b]{2}{*}{2018} & Conventional & 0.5155842 & 0.6937012 & 0.5294748 & 0.5775769 \\
\hline & Takaful/Islamic & 0.1071302 & 0.1314811 & 0.1071302 & 0.0564280 \\
\hline \multirow[b]{2}{*}{2017} & Conventional & 0.4052964 & 0.5240668 & 0.4521251 & 0.4409486 \\
\hline & Takaful/Islamic & 0.1541248 & 0.1811406 & 0.1738828 & 0.2567724 \\
\hline \multirow[b]{2}{*}{2016} & Conventional & 0.4988427 & 0.5105917 & 0.5016776 & 0.5028200 \\
\hline & Takaful/Islamic & 0.1864224 & 0.2271544 & 0.2038428 & 0.8000000 \\
\hline \multirow[b]{2}{*}{2015} & Conventional & 0.5101368 & 0.5957801 & 0.5741934 & 0.6460691 \\
\hline & Takaful/Islamic & 0.2390860 & 0.2745545 & 0.2587022 & 0.4771530 \\
\hline \multirow[b]{2}{*}{2014} & Conventional & 0.5382361 & 0.6177414 & 0.5755626 & 0.6528324 \\
\hline & Takaful/Islamic & 0.1984470 & 0.2379467 & 0.2152922 & 0.3774458 \\
\hline \multirow[b]{2}{*}{2013} & Conventional & 0.5235505 & 0.5775096 & 0.5439949 & 0.5986987 \\
\hline & Takaful/Islamic & 0.1977872 & 0.2321063 & 0.2132027 & 0.2970660 \\
\hline \multirow[b]{2}{*}{2012} & Conventional & 0.5898103 & 0.6581289 & 0.6191132 & 0.5618040 \\
\hline & Takaful/Islamic & 0.1874872 & 0.2016758 & 0.2003848 & 0.2732052 \\
\hline \multirow[b]{2}{*}{2011} & Conventional & 0.6993768 & 0.7391079 & 0.7054375 & 0.6998476 \\
\hline & Takaful/Islamic & 0.2088080 & 0.2255253 & 0.2143682 & 0.3602518 \\
\hline \multirow[b]{2}{*}{2010} & Conventional & 0.6648450 & 0.7017459 & 0.6946774 & 0.6185560 \\
\hline & Takaful/Islamic & 0.1737906 & 0.1901914 & 0.1749296 & 0.3351410 \\
\hline \multirow[b]{2}{*}{2009} & Conventional & 0.6290017 & 0.6766141 & 0.6592849 & 0.7287056 \\
\hline & Takaful/Islamic & 0.1590032 & 0.1862524 & 0.1723799 & 0.3823986 \\
\hline \multirow[b]{2}{*}{2008} & Conventional & 0.5403482 & 0.6562232 & 0.5785025 & 0.5720288 \\
\hline & Takaful/Islamic & 0.1162236 & 0.1279189 & 0.1162236 & 0.2451062 \\
\hline \multirow[b]{2}{*}{2007} & Conventional & 0.3354161 & 0.4578235 & 0.3994393 & 0.3190636 \\
\hline & Takaful/Islamic & 0.3431346 & 0.4090685 & 0.3431346 & 0.3208310 \\
\hline
\end{tabular}




\section{Mll Macrothink}

Business Management and Strategy ISSN 2157-6068 2019, Vol. 10, No. 2

The Table shows the mean efficiency values of cost (CE), allocative (AE), scope (SE), and variable return scale (VRS). VRS has been used for comparison that which year performed well.

The study reveals that mean efficiency scores are low to medium and volatile throughout the sample period. 2009 indicates highest efficiency score while 2007 has lowest of conventional insurance companies. As we compare takaful firms, 2016 reveals highest score and 2018 states lowest. If we analyze global financial crises period, it is stated that in 2007 both takaful and conventional companies are working at same level, overall efficiency of conventional firms is lower than 2008 but takaful firms are operating better in 2007 than in 2008. We suggest that in post-crises period, conventional firms gave best in 2009 and takaful firms in 2016. Average of whole sample imply that the efficiency score of cost, allocative and scope efficiencies of conventional firms are $0.5375371,0.6174195,0.5694569$ respectively, which means that firms wasted around $50 \%$ of its resources that could be used to reduce the cost and produce more amount of output or cost can be reduced by $50 \%$ and still produce the same amount of output as before.

Low average efficiency score (CE, AE and SE) of takaful firms from 2007 to 2018 are spotted during the sample period; $0.2251543,0.2592462,0.2379834$ respectively. It can be said that managers didn't use their resources efficiently to produce output or firms are operating at high level of inefficiency. According to the statistics only few companies were in a position to move their production frontier. Security General Insurance Company Limited solely fulfilled this criterion. It can be said that political instability could be an important cause of deterioration in efficiency.

Table 4. year-wise mean efficiency scores

\begin{tabular}{|c|c|c|c|c|c|}
\hline & \multicolumn{4}{|c|}{ BANKS } \\
\hline & & $\mathbf{C E}$ & $\mathbf{A E}$ & SE & VRS \\
\hline \multirow[b]{2}{*}{2018} & Conventional & 0.7223327 & 0.7701868 & 0.7329253 & 0.8956897 \\
\hline & Takaful/Islamic & 0.7042910 & 0.7649058 & 0.7042910 & 0.9268520 \\
\hline \multirow[b]{2}{*}{2017} & Conventional & 0.7396083 & 0.8158750 & 0.7653699 & 0.9389657 \\
\hline & Takaful/Islamic & 0.6877798 & 0.7336819 & 0.7207462 & 0.9781766 \\
\hline \multirow[b]{2}{*}{2016} & Conventional & 0.7584123 & 0.8212496 & 0.7767827 & 0.9444362 \\
\hline & Takaful/Islamic & 0.6870706 & 0.7330010 & 0.6884981 & 0.9334280 \\
\hline \multirow[b]{2}{*}{2015} & Conventional & 0.7267500 & 0.8396621 & 0.7861079 & 0.9333589 \\
\hline & Takaful/Islamic & 0.6183052 & 0.7411270 & 0.7141142 & 0.9491182 \\
\hline \multirow[b]{2}{*}{2014} & Conventional & 0.7833670 & 0.8596989 & 0.8287674 & 0.9537935 \\
\hline & Takaful/Islamic & 0.7622012 & 0.7622012 & 0.7622012 & 1.0000000 \\
\hline \multirow[b]{2}{*}{2013} & Conventional & 0.7531620 & 0.7981105 & 0.7748779 & 0.9615072 \\
\hline & Takaful/Islamic & 0.7581716 & 0.7744813 & 0.7744813 & 1.0000000 \\
\hline 2012 & Conventional & 0.8026197 & 0.8648436 & 0.8224165 & 0.9472546 \\
\hline
\end{tabular}




\begin{tabular}{|l|l|l|l|l|l|} 
& Takaful/Islamic & 0.7616412 & 0.7993508 & 0.7993508 & 1.0000000 \\
\hline \multirow{2}{*}{$\mathbf{2 0 1 1}$} & Conventional & 0.7991994 & 0.8519795 & 0.8202853 & 0.9606058 \\
\hline \multirow{2}{*}{$\mathbf{2 0 1 0}$} & Takaful/Islamic & 0.7728882 & 0.7823901 & 0.7823901 & 1.0000000 \\
\hline \multirow{2}{*}{$\mathbf{2 0 0 9}$} & Conventional & 0.7451578 & 0.8271064 & 0.7856939 & 0.9438085 \\
\hline \multirow{3}{*}{$\mathbf{2 0 0 8}$} & Takaful/Islamic & 0.7304314 & 0.7365740 & 0.7320739 & 0.9948066 \\
\hline \multirow{2}{*}{$\mathbf{2 0 0 7}$} & Conventional & 0.7292895 & 0.8093675 & 0.7839587 & 0.9626193 \\
& Takaful/Islamic & 0.7576578 & 0.7939729 & 0.7722071 & 0.9618502 \\
\hline & Conventional & 0.7203190 & 0.7794286 & 0.7536730 & 0.9463949 \\
& Takaful/Islamic & 0.7745080 & 0.7915681 & 0.7789424 & 0.9865168 \\
\hline & Conventional & 0.6243727 & 0.6995599 & 0.6482744 & 0.7629065 \\
& Takaful/Islamic & 0.4300694 & 0.4761516 & 0.4493058 & 0.7726800 \\
\hline
\end{tabular}

The mean efficiency scores are medium to high and almost constant between $70 \%$ to $80 \%$ throughout the sample period. 2009, 2011 and 2013 indicates highest efficiency score while 2007 indicates lowest of conventional banks. As we compare Islamic banks, 2011 to 2014 reveals highest score and fully efficient meanwhile 2007 states lowest. If we analyze the period of financial crisis it is stated that in 2007 both conventional and Islamic banks are working at same position, overall efficiency of conventional and Islamic banks are lower in 2007 than in 2008. Impacts of financial crisis didn't evidence in 2008 and was operating efficiently in comparison with 2007. Post-crisis period states that, conventional banks gave best in 2011 and 2013 and Islamic banks in 2011 to 2014. Average scores of cost, allocative and scope efficiencies of conventional banks are 0.7420492, 0.8114224, 0.7732611 respectively, which means that banks as on average, thought were about to be operating their inputs efficiently with only insignificant changes over spell to produce the best amount of output.

Average efficiency score (CE, AE and SE) of Islamic banks from 2007 to 2018 are 0.7068978 , $0.7446602,0.7289643$ separately. Islamic and Conventional banks are operating almost at the equal level of efficiency. Findings depict that from 2008 to 2013 efficiency increases while from 2014 to 2018 slight decline was observed. High interest rate can be the reason in reduction in efficiency because it increases the problems of non-performing loan and financial costs of the capital which leads to low cost efficiency of the banking sector.

Findings of efficiency model suggest that banking sector of Pakistan is more productively operated than insurance sector, but insurance sector has a great potential to flourish in some years because its profitability ratios are better than banking sector.

\subsubsection{Independent t Test}

This test employs for comparing the means of two different sets and notify that the population means of different groups are significantly dissimilar or not. 
Table 5. Efficiency Score Comparison by Independent t-Test

\begin{tabular}{|c|c|c|c|c|}
\hline \multicolumn{2}{|c|}{ Insurance Sector } & CE & AE & SE \\
\hline No. of Years & N & 12 & 12 & 12 \\
\hline & CON & 0.53750 & 0.61740 & 0.56950 \\
Mean & ISL & 0.18930 & 0.21880 & 0.19950 \\
\hline & CON & 0.10215 & 0.08637 & 0.09262 \\
St. Dev & ISL & 0.06118 & 0.07351 & 0.06199 \\
\hline Levene's Test & Prob. & 0.18000 & 0.30300 & 0.19000 \\
\hline & Prob. & 0.00000 & 0.00000 & 0.00000 \\
T-test & MD & 0.34825 & 0.39867 & 0.37000 \\
\hline
\end{tabular}

The significant difference is analyzed between standard deviations and means of conventional and Islamic sectors for N; 12 years. Results of "F statistic" shows p-value is higher than 0.05 so that it can be said that the assumption of equal variances are not violated, meaning of that, the distribution of cost, allocative and scope efficiencies of conventional insurance sector is similar in shape to the distribution of Islamic insurance sector. The value of "t-statistic" with a p-value of 0.000 is less than 0.0005 which means that the null hypothesis is not accepted because mean scores are not evidenced the significant difference, so the chance of happening this event is trivial

Table 6. Efficiency Score Comparison by Independent t-Test

\begin{tabular}{|c|c|c|c|c|}
\hline \multicolumn{2}{|c|}{ Banking Sector } & CE & AE & SE \\
\hline No. of Years & N & 12 & 12 & 12 \\
\hline & CON & 0.74200 & 0.81140 & 0.77330 \\
Mean & ISL & 0.70380 & 0.74080 & 0.72320 \\
\hline & CON & 0.04686 & 0.04613 & 0.04848 \\
St. Dev & ISL & 0.09810 & 0.08681 & 0.09328 \\
\hline Levene's Test & Prob. & 0.14900 & 0.54100 & 0.30400 \\
\hline & Prob. & 0.23500 & 0.02100 & 0.11300 \\
T-test & MD & 0.03830 & 0.07064 & 0.05004 \\
\hline
\end{tabular}

Table shows results of efficiency comparison between conventional sector and Islamic sector. No significant difference is investigated between standard deviations and means of conventional and Islamic sectors for $\mathrm{N} ; 12$ years. Results of "F statistic" shows $\mathrm{p}$-value is higher than 0.05 so that it can be said that the assumption of equal variances are not violated, meaning of that, the distribution of cost, allocative and scope efficiencies of conventional banking sector is similar in shape to the distribution of Islamic banking sector. The value of "t-statistic" of allocative efficiency along p-value of 0.021 is less than 0.05 which means that the null hypothesis is not accepted because mean scores are not evidenced the significant difference, so the chance of happening this event is trivial, whereas, p-value of "t-statistic" of cost and scope efficiencies are more than 0.05 , means that the null hypothesis is accepted due 


\section{Mll Macrothink}

to significant differences.

\subsection{Results of Stage 2}

\subsubsection{Tobit Regression Analysis}

Our ultimate objective is to evaluate determinants of efficiency scores. The dependent variables for this purpose are efficiency scores (cost efficiency, allocative efficiency, scope efficiency) and independent variables are determinants of efficiency (size, leverage, ROA, CAR, age and dummy variables). Three regression equations are estimated to see the effect independent variables over dependent variable.

Table 7. Regression results of determinants of insurance sector

\begin{tabular}{|c|c|c|c|c|c|c|}
\hline \multicolumn{7}{|l|}{ Insurance Sector } \\
\hline \multirow{2}{*}{$\begin{array}{l}\text { Dependent Variable } \\
\text { Independent } \\
\text { Variable }\end{array}$} & \multicolumn{2}{|l|}{$\mathbf{C E}$} & \multicolumn{2}{|l|}{$\mathbf{A E}$} & \multicolumn{2}{|l|}{ SE } \\
\hline & Coefficient & Prob. & Coefficient & Prob. & Coefficient & Prob. \\
\hline $\mathbf{C}$ & 0.242529 & 0.0501 & 0.119738 & 0.4488 & 0.079014 & 0.6756 \\
\hline SIZE & 8.08E-06 & $0.0000 * * *$ & $-2.03 \mathrm{E}-06$ & $0.0643 *$ & $3.50 \mathrm{E}-06$ & $0.0064 * * *$ \\
\hline LEVERAGE & $2.51 \mathrm{E}-01$ & $0.0342 *$ & $5.03 \mathrm{E}-01$ & $0.0008 * * *$ & 4.19E-01 & $0.0201 *$ \\
\hline ROA & -0.159658 & 0.1966 & 0.324477 & $0.042 *$ & 0.018756 & 0.9197 \\
\hline CAR & 0.524161 & $0.0000 * * *$ & 0.703635 & $0.0000 * * *$ & 0.696083 & $0.0002 * *$ \\
\hline AGE & $1.25 \mathrm{E}-03$ & $0.0465 *$ & -0.000683 & 0.3982 & 0.001905 & $0.0433 *$ \\
\hline GFC & -0.219975 & $0.0000 * * *$ & 0.193404 & $0.0004 * *$ & -0.153136 & $0.0161 *$ \\
\hline Isl & -0.227317 & $0.0000 * * *$ & -0.432682 & $0.0000 * * *$ & -0.265981 & $0.0001 * *$ \\
\hline CASR & $-7.35 \mathrm{E}-06$ & $0.0000 * * *$ & $-5.13 \mathrm{E}-07$ & 0.7315 & $-6.08 E-06$ & $0.0005 * *$ \\
\hline
\end{tabular}

*: Statistically Significant at 10\%, **: Statistically Significant at $0.05 \%$, ***: Statistically significant at $1 \%$

\subsubsection{Interpretation of Cost Efficiency}

We employed Balanced pooled Data for these regression results. Positive coefficients are found in the regression results except ROA, CASR and Dummy variables. DV Isl elaborates that Takaful Firms have a lower CE scores of 0.227 in comparison to conventional Insurance firms and dummy variable GFC tells period of global financial crisis $(D=1)$ have a lower CE scores of 0.219 over post global crisis period $(\mathrm{D}=0)$. At level 3; LEVERAGE and AGE are being significant, while, at level 1; SIZE, CAR, dummy variable Isl, dummy variable GFC and CASR are significant. ROA variable is insignificant at $p$ value 0.1966 .

Size and Capital Adequacy, the two firm definite variables denote positive coefficient and are significant in model. The outcomes of the test suggest that positive impact is observed of firm size and capital ratio on insurance sector's efficiency in Pakistan. The results explicate that during period of financial and post-financial crisis, larger firms at least technically hold their resources and can sustain positive capital adequacy ratio. ROA has negative relationship of 
profitability with efficiency, which signifies that during the global and post global crisis period technically efficient and well financed firms also have lower profitability and AGE is positively correlated with efficiency means that one increases the other will also increase. A negative relationship of CASR with efficiency depicts that stock market volatility does not affect cost efficiency of firms in insurance sector of Pakistan's Stock Market.

Four variables (SIZE, LEVERAGE, CAR and AGE) out of five independent variables are significantly influencing Cost Efficiency scores and the effect of ROA variable is found insignificant on CE scores.

\subsubsection{Interpretation of Allocative Efficiency}

Independent variables i.e. AGE and SIZE have negative correlation with Allocative Efficiency scores so that as AGE and SIZE increase it will disturb AE scores of the firm negatively, means newly incorporated insurance firms have higher competency rather than the older firms. Conversely, Allocative Efficiency scores are positively affected by LEVEARGE variable, simultaneously as Leverage increases it will influence AE scores also. SIZE, ROA and GFC Dummy Variable are significant at level 3 (first two variables) and level 2 respectively, means profitability has a positive impact on efficiency. Takaful Firms "1" have a lower AE scores of 0.433 in comparison to Conventional Insurance firms " 0 ". Dummy variable GFC tells period of global financial crisis $(D=1)$ over post global crisis period $(D=0)$ is positively correlated with efficiency, which means efficiency of firms are not affected from financial crisis in Pakistan. At Level 1, LEVERAGE, CAR and Dummy Variable Isl are highly significant, whereas other variables are insignificant. CASR shows negative relationship that means News and Events that are reflected from the performance of Stock Market are not witnessed in the Allocative Efficiency.

\subsubsection{Interpretation of Scope Efficiency}

Last column of Tobit regression analysis demonstrates the linkage with Scope Efficiency score, in which positive relationship is found between SE scores and ROA of the insurance firm, it could be said that firms have utilized their assets efficiently to make the firm profitable. A positive ROA ratio reveals that firms are more competent because firms have decent amount of assets to efficiently produce good results of net income. Dependent Variable SE scores of the firms are also positively correlated with SIZE and LEVERAGE. It is stated that, firm would be more efficient if the size of total assets increases. At level 3, LEVERAGE, AGE and Dummy Variable GFC are significant, whereas, at level 2; CAR, Dummy Variable Isl and CASR are significant. Only ROA is being insignificant on Scope Efficiency. Coefficient of Dummy Variables have negative relationship i.e. period of global financial crisis $(D=1)$ have a lower SE scores of 0.1531 over post global crisis period $(D=0)$. DV Isl elaborates that Takaful Firms have a lower SE scores of 0.2660 in comparison to conventional Insurance firms. Negative impact of CASR on efficiency shows that results of stock market volatility that are happening nationally does not influence scope efficiency of firms. 
Table 8 Regression results of determinants of banking sector

\begin{tabular}{|l|l|l|l|l|l|l|}
\hline \multicolumn{6}{|l|}{ Banking Sector } \\
\hline Dependent Variable & \multicolumn{2}{l|}{ CE } & \multicolumn{2}{l|}{ AE } & \multicolumn{2}{l|}{ SE } \\
\hline Independent Variable & Coefficient & Prob. & Coefficient & Prob. & Coefficient & Prob. \\
\hline C & 0.705639 & 0.0000 & 0.797443 & 0.0000 & 0.711222 & 0.0000 \\
SIZE & $1.04 \mathrm{E}-07$ & $0.0118^{*}$ & $4.37 \mathrm{E}-08$ & 0.2891 & $7.62 \mathrm{E}-08$ & $0.0636^{*}$ \\
LEVERAGE & $4.54 \mathrm{E}-07$ & 0.7173 & $2.51 \mathrm{E}-07$ & 0.8409 & $1.69 \mathrm{E}-06$ & 0.1746 \\
ROA & 0.208105 & 0.5058 & 0.454561 & 0.146 & 0.27389 & 0.3792 \\
CAR & 0.417035 & $0.0113^{*}$ & 0.429173 & $0.0091 * * *$ & 0.618138 & $0.0002 * *$ \\
AGE & $5.30 \mathrm{E}-05$ & 0.9270 & -0.000372 & 0.5196 & -0.000214 & 0.7101 \\
GFC & -0.131823 & $0.0124^{*}$ & -0.157042 & $0.0029 * * *$ & -0.062107 & 0.2363 \\
Isl & -0.026156 & 0.5312 & -0.077237 & $0.0643 *$ & -0.030817 & 0.4585 \\
CASR & $-2.61 \mathrm{E}-06$ & $0.0815^{*}$ & $-1.78 \mathrm{E}-06$ & 0.235 & $-2.07 \mathrm{E}-06$ & 0.165 \\
\hline
\end{tabular}

*: Statistically Significant at $10 \%$, **: Statistically Significant at $0.05 \%$, ***: Statistically significant at $1 \%$

\subsubsection{Interpretation of Cost Efficiency}

Table 8 shows regression results for the determinants of efficiency. Positive Coefficients are found in the regression model except CASR and Dummy variables. Dummy variable Isl expresses that Islamic banks have a lower CE scores of 0.0262 in comparison to conventional banks and dummy variable GFC tells period of global financial crisis $(D=1)$ have a lower $C E$ scores of 0.1318 over post global crisis period $(\mathrm{D}=0)$. At level 3; SIZE, CAR, CASR and GFC dummy variable (period of Global Financial Crisis) are significant, whereas LEVERAGE, ROA, AGE and Isl dummy variable (Islamic Banks) are insignificant with $p$ values of $0.7173,0.5058,0.9270$ and 0.5312 respectively.

Size and Capital Adequacy, the two definite variables denote positive coefficients and are significant in model. The outcomes of the test suggest that positive impact is observed of size and capital ratio on bank's efficiency. The results explicate that during period of financial and post-financial crisis, larger banks at least technically hold their resources and sustain constructive capital adequacy ratio. ROA is insignificant which means it is not perfectly contributed towards profitability of banks, which signifies that during the global and post global crisis period technically efficient and well financed banks also have lower profitability. LEVERAGE and AGE are insignificant with efficiency which means if one increases it does not make the reason to support the bank efficiently in generating profits. A negative relationship of CASR with efficiency depicts that stock market volatility does not affect cost efficiency of firms in banking sector of Pakistan's Stock Market.

\subsubsection{Interpretation of Allocative Efficiency}

Independent variable i.e. AGE has negative correlation and is insignificant with efficiency scores, so that, as AGE increases it will disturb AE scores of the bank negatively, means 
newly incorporated banks have higher competency rather than the older banks. Conversely, SIZE, LEVEARGE, and ROA variable have insignificant impact on AE scores, as Leverage and SIZE increase it will not influence AE scores. Only independent variable CAR is significant at level 1 , means banks have ability to meet its obligations proficiently and profitability impacts efficiency positively. At level 1, dummy variable of Crisis and at level 3, dummy variable of Islamic banks are significant. Islamic Banks "1" have a lower AE scores of 0.0772 in comparison to Conventional Banks "0". Dummy variable GFC tells period of global financial crisis $(D=1)$ have a lower AE scores of 0.1570 over post global crisis period $(D=0)$, means efficiency of banks are affected from financial crisis in Pakistan. At Level 1, Solely CAR is highly significant, however other variables are insignificant. CASR shows negative relationship that means News and Events that are reflected from the performance of Stock Market are not witnessed in the Allocative Efficiency.

Four variables (SIZE, LEVERAGE, ROA and AGE) out of five independent variables are insignificantly influencing the Allocative Efficiency scores. All alone CAR variable impacts AE scores significantly.

\subsubsection{Interpretation of Scope Efficiency}

Last column of Tobit regression analysis demonstrates the linkage with Scope Efficiency score, in which positive relationship is found between SE scores and CAR variable and is significant at level 2, it could be said that banks have utilized its assets efficiently to make the entity profitable. A positive CAR illustrates that banks can face unexpected losses when they have fair investments. Rest of the variables are insignificant. It can be said that insignificant ROA reveals that banks are less competent, so it is enough critical for investors because bank's assets are not able to efficiently produce good results of net income. However, as LEVERAGE increases, banks would not be more efficient. At level 3, SIZE is significant and positively correlated with dependent variable. AGE variable is negatively correlated with efficiency and is insignificant. Dummy variable GFC and Isl are insignificant with the Scope Efficiency. Coefficient of Dummy Variables have negative relationship i.e. period of global financial crisis $(D=1)$ have a lower SE scores of 0.0621 over post global crisis period $(D=0)$. DV Isl elaborates that Islamic Banks have a lower SE scores of 0.0308 in comparison to Conventional Banks. Negative impact of CASR on efficiency shows that results of stock market volatility that are happening nationally does not influence scope efficiency of firms.

\subsubsection{Correlation}

Table 9. Correlation

\begin{tabular}{|l|c|c|c|c|c|c|c|c|c|c|c|}
\hline \multicolumn{1}{|l|}{ Insurance Sector } & Size & Leverage & ROA & CAR & Age & GFC & Isl & CASR & CE & AE & SE \\
\hline Size & 1 & & & & & & & & & & \\
\hline Leverage & 0.316 & 1 & & & & & & & & & \\
\hline ROA & 0.063 & -0.137 & 1 & & & & & & & & \\
\hline
\end{tabular}




\begin{tabular}{|l|c|c|c|c|c|c|c|c|c|c|c|}
\hline CAR & -0.27 & -0.703 & 0.206 & 1 & & & & & & & \\
\hline Age & 0.294 & 0.071 & 0.185 & 0.074 & 1 & & & & & & \\
\hline GFC & -0.12 & -0.191 & 0.055 & 0.072 & $-1 \mathrm{E}-17$ & 1 & & & & & \\
\hline Isl & -0.16 & -0.086 & -0.165 & -0.187 & -0.51 & $7 \mathrm{E}-17$ & 1 & & & & \\
\hline CASR & 0.248 & 0.081 & 0.050 & -0.065 & $-2 \mathrm{E}-17$ & -0.460 & $-8 \mathrm{E}-18$ & 1 & & & \\
\hline CE & 0.430 & 0.080 & 0.042 & 0.102 & 0.364 & -0.165 & -0.393 & -0.086 & 1 & & \\
\hline AE & -0.09 & -0.088 & 0.195 & 0.278 & 0.176 & 0.197 & -0.438 & -0.119 & 0.114 & 1 & \\
\hline SE & 0.158 & -0.004 & 0.090 & 0.159 & 0.292 & -0.068 & -0.336 & -0.094 & 0.632 & 0.226 & 1 \\
\hline
\end{tabular}

The correlation between dependent variable $\mathrm{CE}$ and independent variable Size and Age are almost moderate positive relationship. Leverage, ROA and CAR have low positive correlation and Dummy variable Isl has almost moderate negative relationship with CE. Dummy variable GFC and CASR have low negative correlation means both variables move in an opposite direction at a time.

Size, Leverage and CASR have low negative relationship with dependent variable AE. Dummy variable Isl has a moderate negative relationship with $\mathrm{AE}$. Other independent variables (ROA, CAR, Age and Dummy variable GFC) have low positive relationship.

Independent variables Size, ROA, CAR and Age have low correlation while other remaining variables have low negative relationship with SE. So, it can be concluded that both dependent and independent variable doesn't strongly impact each other. Only independent variable Age lies in between moderate relationship with dependent variables.

Table 10. Correlation

\begin{tabular}{|c|c|c|c|c|c|c|c|c|c|c|c|}
\hline \multicolumn{12}{|c|}{ Banking Sector } \\
\hline & Size & Leverage & ROA & CAR & Age & GFC & CASR & IsI & CE & $\mathbf{A E}$ & SE \\
\hline Size & 1 & & & & & & & & & & \\
\hline Leverage & -0.02 & 1 & & & & & & & & & \\
\hline ROA & 0.100 & -0.049 & 1 & & & & & & & & \\
\hline CAR & -0.14 & -0.089 & -0.072 & 1 & & & & & & & \\
\hline Age & 0.335 & -0.016 & 0.062 & -0.034 & 1 & & & & & & \\
\hline GFC & -0.22 & 0.145 & -0.079 & 0.125 & $7 \mathrm{E}-18$ & 1 & & & & & \\
\hline CASR & 0.372 & -0.047 & 0.117 & -0.114 & $-3 E-18$ & -0.460 & 1 & & & & \\
\hline Isl & -0.12 & -0.037 & 0.015 & 0.046 & -0.311 & 0 & $-3 \mathrm{E}-17$ & 1 & & & \\
\hline $\mathbf{C E}$ & 0.161 & -0.017 & 0.048 & 0.121 & 0.080 & -0.128 & 0.003 & -0.061 & 1 & & \\
\hline $\mathbf{A E}$ & 0.075 & -0.031 & 0.091 & 0.127 & 0.021 & -0.164 & 0.027 & -0.110 & 0.937 & 1 & \\
\hline SE & 0.081 & 0.054 & 0.041 & 0.208 & 0.031 & -0.020 & -0.042 & -0.052 & 0.927 & 0.908 & 1 \\
\hline
\end{tabular}

Independent variable Size, ROA, CAR, Age and CASR have low positive correlation with dependent variable CE. Leverage and Dummy variables GFC and Isl have low negative relationship. 
Correlation between dependent variable AE and independent variable Size, ROA, CAR, Age and CASR have low positive relationship while Leverage and Dummy variables GFC and Isl have low negative relationship.

All five firm specific variables Size, Leverage, ROA, CAR and Age have low positive correlation with SE whereas both Dummy variables and CASR have low negative relationship. It can be seen that all dependent variables have strong positive correlation with each other.

\section{Conclusion}

This paper investigates the allocative, cost and scope efficiencies and gain insight on determinants that affect efficiency in banking and Insurance sector. This comparative analysis gets insight regarding sectors' performance and studies the impact of stock market fluctuations and global financial crisis 2007-2008 on efficiencies of these sectors.

The results suggest that, on average, banking sector of Pakistan is technically more efficient than insurance sector, but insurance sector has a great potential for future because of higher profitability ratios (ROA and CAR). Islamic banks and conventional banks are almost efficient at same level. The average results of Allocative, Cost and Scope Efficiencies of conventional banks and Islamic bank are comparable, that is, 0.7420492, 0.8114224 and 0.773261 respectively for conventional banks and $0.7068978,0.7446602$ and 0.7289643 respectively for Islamic banks. Conventional insurance companies are more efficiently operated than Islamic Insurance (takaful) as reflected from the results of their three efficiencies, that is, $0.5375371,0.6174195$ and 0.5694569 for conventional insurance sector, and $0.2251543,0.2592462$ and 0.2379834 for Islamic insurance(takaful).

Correlation exhibits that dependent and independent variable doesn't strongly impact each other. Only independent variable Age lies in between moderate relationship with dependent variables in insurance industry whereas, all dependent variables have strong positive correlation with each other in banking sector.

Regression results show negative impact of global financial crisis and stock market volatility on Cost Efficiency of banking sector although other determinants show positive relationship. Islamic banks show lower CE scores than conventional banks. Allocative and Scope Efficiency also show same relationship with determinants as has been the Cost Efficiency. Only negative relationship has found between AGE variable and both efficiencies (Allocative and Scope Efficiency). Negative relationship has analyzed between ROA and Cost Efficiency of the Insurance sector in Pakistan while stock market performance affects negatively to all type of efficiency score of insurance sector. Global financial crisis negatively impacts Cost and Scope Efficiency except Allocative Efficiency. Takaful firms show lower efficiency scores of all type of efficiency while other determinants remain positive with Cost Efficiency. Allocative Efficiency has influenced negatively with determinants i.e. SIZE and AGE however other determinants are positive in nature. All determinants positively impact Scope Efficiency. 


\section{Al Macrothink}

Business Management and Strategy

ISSN 2157-6068

2019, Vol. 10, No. 2

This study provides insights to the policymakers regarding improvement in administrative know-how, optimum consumption of capacities, effective apportionment of rare resources, and the utmost fruitful scale of operation of both sectors of Pakistan. As, Total Assets have a significant impact on the efficiency scores, so the firms and banks should emphasis on total assets. Similarly, for both sectors' efficiencies, Leverage is a noteworthy contributor so that the firms and banks emphasis on the fuel of exterior resources for increasing entity's Assets. Takaful firms have a good opportunity to attract the existing clients of conventional insurance under the umbrella of Shariah Compliant takaful firms by financing in new vigorous plans. Takaful as an emerging branch of insurance, has a great potential because Age of the firm doesn't affect the performance of the sector so new entrants can easily adjust in this sector.

\section{References}

Abbas, M., Khan, A. B., Abbasi, S., \& Mahmood, Z. (2018). Determinants of Cost Efficiency of Takaful and Conventional Insurance Firms of Pakistan. Review of Economics and Development Studies, 4(2), 331-340. https://doi.org/10.26710/reads.v4i2.418

Abidin, Z. A. (2011). Efficiency of Non-Life Insurance in Indonesia. Journal of Economics, Business and Accountancy Venture. https://doi.org/10.14414/jebav.v14i3.46

Abugamea, G. (2018). Determinants of Banking Sector Profitability: Empirical Evidence from Palestine.

Adjei-Frimpong, K., Gan, C., \& Hu, B. (2014). Cost efficiency of Ghana’s banking industry: A panel data analysis. The International Journal of Business and Finance Research, 8(2), 69-86.

Aftab, M., Ahamad, S., Ullah, W., \& Sheikh, R. A. (2011). The impact of bank efficiency on share performance: Evidence from Pakistan. African Journal of Business Management, 5(10), 3975-3980.

Asghar, A., e Kausar, M. J., \& Afza, T. (2010). Efficiency of the Insurance Industry in Pakistan: An Application of Non-Parametric Approach. Interdisciplinary Journal of Contemporary Research in Business, 2(8).

Antonio, M. S., Ali, M. M., \& Akbar, N. (2013). A comparative analysis of the efficiency of takaful and conventional insurance in Malaysia. International Journal of Excellence in Islamic Banking and Finance, 182(881), 1-13. https://doi.org/10.12816/0001416

Hakan, A., Ensar, Y., Bülent, G., \& İlhan, K. (2015). The relationship between stock performance and the efficiency in Turkish banking sector.

Aziz, S., Husin, M., \& Hashmi, S. H. (2016). Performance of Islamic and Conventional Banks in Pakistan: A Comparative Study. International Journal of Economics and Financial Issues, 6(4), 1383-1391.

Banna, H., Ahmad, R., \& Koh, E. H. (2017). Determinants of commercial banks' efficiency 
in Bangladesh: does crisis matter?. The Journal of Asian Finance, Economics and Business (JAFEB), 4(3), 19-26. https://doi.org/10.13106/jafeb.2017.vol4.no3.19

Biener, C., Eling, M., \& Wirfs, J. H. (2016). The determinants of efficiency and productivity in the Swiss insurance industry. European Journal of Operational Research, 248(2), 703-714. https://doi.org/10.1016/j.ejor.2015.07.055

Brown, C. (2019). Difference Between Islamic Banking and Conventional Banking. Retrieved from Islamic Institute | AIMS UK: http://www.aims.education/study-online/difference-between-islamic-banking-and-convention al-banking-system/

Effendi, N., Setiawan, M., Emvalomatis, G., \& Lansink, O. A. (n.d.). Banking Efficiency and Macroeconomic Factors: Evidence from Indonesian Banking Sector. University of Padjadjaran, Faculty of Economics and Business.

Eltivia, N., Rosidi, M., \& Saraswati, E. (2014). The effect of cost efficiency on stock performance of listed bank in Indonesia. International Journal of Economic Resources, 5i2, $50-56$.

Grmanová, E., \& Strunz, H. (2017). Efficiency of insurance companies: Application of DEA and Tobit analyses. Journal of International Studies, 10(3), 250-263. https://doi.org/10.14254/2071-8330.2017/10-3/18

Hadad, M. D., Hall, M. J., Kenjegalieva, K. A., Santoso, W., \& Simper, R. (2011). Banking efficiency and stock market performance: an analysis of listed Indonesian banks. Review of Quantitative Finance and Accounting, 37(1), https://doi.org/10.1007/s11156-010-0192-1

Hamid, K., \& Khurram, M. (2017). Comparative Analysis of Technical Efficiency for Islamic versus Conventional Banks and its Determinants in Pakistan. Hamid, K., \& Khurram, MU (2017). Comparative Analysis of Technical Efficiency for Islamic versus Conventional Banks and its Determinants in Pakistan. Journal of Islamic Business and Management, 7(2), 197-210. https://doi.org/10.2139/ssrn.2911581

Hussain, I. (2015). Macro economy and profitability of insurance companies: a post crisis scenario in Pakistan. Pakistan business review, 17(2), 243-263.

Janjua, P. Z., \& Akmal, M. (2015). A comparative analysis of economic efficiency of conventional and Islamic insurance industry in Pakistan. Pakistan Business Review, 17(1), 21-44.

Jurčević, B., \& Žaja, M. M. (2013). Banks and insurance companies efficiency indicators in the period of financial crisis: The case of the Republic of Croatia. Economic research-Ekonomska istraživanja, $203-224$. https://doi.org/10.1080/1331677X.2013.11517598 
Kader, H. A., Adams, M., \& Hardwick, P. (2010). The cost efficiency of takaful insurance companies. The Geneva Papers on Risk and Insurance-Issues and Practice, 35(1), 161-181. https://doi.org/10.1057/gpp.2009.33

Khan, I. U., Ali, S., \& Khan, H. N. (2018). Market Concentration, Risk-taking, and Efficiency of Commercial Banks in Pakistan: An Application of the Two-Stage Double Bootstrap DEA. Business and Economic Review, 10(2), 65-95. https://doi.org/10.22547/BER/10.2.4

Khan, M. K., Nouman, M., TENG, J. Z., Khan, M. I., \& Jadoon, A. U. (2017). Determinants of financial performance of financial sectors (An assessment through economic value added).

Khawja, I. D. (2007). Global Financial Crisis: Policy Implications for Pakistan. NUML Journal of Management \& Technology, 9(1), 20-31.

Maqbool, N., Hameed, W.-U., \& Habib, M. U. (2018). Impact of Political Influences on Stock Returns. International Journal of Multidisciplinary Scientific Publication.

Miah, M. D., \& Uddin, H. (2017). Efficiency and stability: A comparative study between islamic and conventional banks in GCC countries. Future Business Journal. https://doi.org/10.1016/j.fbj.2017.11.001

Mughal, K., Khan, I., \& Usman, F. (2015). The Impacts of Financial Crisis on Pakistan Economy: An Empirical Approach. Economic Survey, 2013(14), 4-14.

Nazir, M. S., Safdar, R., \& Akram, M. I. (2012). Impact of global financial crisis on banks' financial performance in Pakistan. American Journal of Scientific Research, ISSN, 2301-2005.

Ndlovu, T. (2015). Determinants of Commercial Banks Profitability in Botswana. University Of Botswana, Department of Economics.

Noreen, U., \& Ahmad, S. (2016). Cost Efficiency and Total Factor Productivity: An Empirical Analysis of Pakistan's Insurance Sector. https://doi.org/10.35536/lje.2016.v21.i1.a5

Nourani, M., Devadason, E. S., \& Chandran, V. G. R. (2018). Measuring technical efficiency of insurance companies using dynamic network DEA: an intermediation approach. Technological and Economic Development of Economy, 24(5), 1909-1940. https://doi.org/10.3846/20294913.2017.1303649

Qureshi, M. A., \& Shaikh, M. (2012). Efficiency of Islamic and conventional banks in Pakistan: a non-parametric approach. International Journal of Business and Management, 7(7), 40. https://doi.org/10.5539/ijbm.v7n7p40

Rahman, M. A. (2015). Comparative study on the efficiency of Bangladeshi conventional and Islamic life insurance industry: a non-parametric approach. Asian Business Review, 3(4), 88-99. https://doi.org/10.18034/abr.v3i4.284 
Řepková, I. (2015). Banking efficiency determinants in the Czech banking sector. Procedia Economics and Finance, 23, 191-196. https://doi.org/10.1016/S2212-5671(15)00367-6

Rusydiana, A. S., \& Nugroho, T. (2017). Measuring Efficiency of Life Insurance Instution in Indonesia: Data Envelopment Analysis Approach. Global Review of Islamic Economics and Business, 5(1), 012-024.

Nair, A. S., \& Vinod, R. (2019). Determinants of the allocative, cost and scope efficiencies of Indian banks. Applied Economics, 51(5), 509-527. https://doi.org/10.1080/00036846.2018.1494815

Sardar, A., Azeem, M. M., Ahmed, T., \& Zafar, S. (2011). Islamic banks: efficiency and its determinants in Pakistan. Islamic Studies, 423-434.

Sufian, F., \& Kamarudin, F. (2016). Determinants of efficiency in the Malaysian banking sector: Does bank origins matter?. Intellectual Economics, 10(1), 38-54. https://doi.org/10.1016/j.intele.2016.04.002

Taib, C. A., Ashraf, M. S., \& Razimi, M. S. B. A. (2018). Technical, Pure Technical and Scale Efficiency: A Non-Parametric Approach of Pakistans Insurance and Takaful Industry. Academy of Accounting and Financial Studies Journal.

Wise, W. (2018). Life insurance company efficiency: best method and proxies. Insurance Markets and Companies. https://doi.org/10.21511/ins.09(1).2018.02

Worthington, A. C., \& Hurley, E. V. (2000). Technical, allocative and cost efficiency in the Australian general insurance industry (Vol. 74). School of Economics and Finance, Queensland University of Technology.

Xiang, D., Shamsuddin, A., \& Worthington, A. C. (2011, August). A comparative technical, cost and profit efficiency analysis of Australian, Canadian and UK banks: Feasible efficiency improvements in the context of controllable and uncontrollable factors. In 24th Australasian Finance and Banking Conference. https://doi.org/10.2139/ssrn.1914094

Yakubu, Z., \& Akerele, A. O. (2012). An analysis of the impact of Global financial Crisis on the Nigerian Stock Exchange. Current Research Journal of Social Sciences, 4(6), 396-399.

Yao, H., Haris, M., \& Tariq, G. (2018). Profitability determinants of financial institutions: evidence from banks in Pakistan. International Journal of Financial Studies, 6(2), 53. https://doi.org/10.3390/ijfs6020053 


\section{Al Macrothink}

Appendix A

\begin{tabular}{|r|r|r|r|r|}
\hline \multicolumn{6}{|c|}{ KSE 100 Index Cumulative Annual Return } & \\
\hline Year & Beginning Price & Ending Price & Stock Returns & Return in Percent \\
\hline $\mathbf{2 0 1 8}$ & 40471.48 & 40789.7 & 318.22 & $0.79 \%$ \\
$\mathbf{2 0 1 7}$ & 47806.97 & 40471.18 & -7335.79 & $-15.34 \%$ \\
$\mathbf{2 0 1 6}$ & 32816.31 & 47806.97 & 14990.66 & $45.68 \%$ \\
$\mathbf{2 0 1 5}$ & 32131.28 & 32816.31 & 685.03 & $2.13 \%$ \\
$\mathbf{2 0 1 4}$ & 25261.14 & 32131.28 & 6870.14 & $27.20 \%$ \\
$\mathbf{2 0 1 3}$ & 16905.33 & 25261.14 & 8355.81 & $49.43 \%$ \\
$\mathbf{2 0 1 2}$ & 11347.66 & 16905.33 & 5557.67 & $48.98 \%$ \\
$\mathbf{2 0 1 1}$ & 12022.16 & 11347.66 & -674.5 & $-5.61 \%$ \\
$\mathbf{2 0 1 0}$ & 9386.92 & 12022.6 & 2635.68 & $28.08 \%$ \\
$\mathbf{2 0 0 9}$ & 5865.01 & 9386.92 & 3521.91 & $60.05 \%$ \\
$\mathbf{2 0 0 8}$ & 14075.83 & 5865.01 & -8210.82 & $-58.33 \%$ \\
$\mathbf{2 0 0 7}$ & 10040.50 & 14075.83 & 4035.33 & $40.19 \%$ \\
\hline
\end{tabular}

\section{Copyright}

Copyright for this article is retained by the author(s), with first publication rights granted to the journal.

This is an open-access article distributed under the terms and conditions of the Creative Commons Attribution license (http://creativecommons.org/licenses/by/4.0/). 